\title{
Response of the Plankton to a Fresh Water Pulse in a Fresh Water Deprived, Permanently Open South African Estuary
}

\author{
Pierre William Froneman $^{1^{*}}$, Paul Denzi Vorwerk ${ }^{2}$ \\ ${ }^{1}$ Coastal Research Group, Department of Zoology and Entomology, Rhodes University, Grahamstown, South Africa \\ ${ }^{2}$ South African Environmental Observation Network (SAEON) Elwandle Node, Grahamstown, South Africa \\ Email: *w.froneman@ru.ac.za
}

Received January 17, 2013; revised February 28, 2013; accepted March 10, 2013

Copyright (C) 2013 Pierre William Froneman, Paul Denzi Vorwerk. This is an open access article distributed under the Creative Commons Attribution License, which permits unrestricted use, distribution, and reproduction in any medium, provided the original work is properly cited.

\begin{abstract}
This study assessed the influence of a freshwater pulse on selected physico-chemical and biological variables in a permanently open freshwater deprived southern African estuary. In the absence of the freshwater pulse a reverse gradient in salinity was evident with hypersaline (salinity $>40$ ) conditions prevailing in the upper reaches of the estuary. Total chlorophyll- $a$ (chl- $a$ ) concentration during this period ranged from 0.25 to $0.60 \mu \mathrm{g} \cdot l^{-1}$. The mean total zooplankton abundance and biomass in the absence of freshwater during the daytime was 666 ind $\cdot \mathrm{m}^{-3}(\mathrm{SD} \pm 196)$ and 12.4 $\mathrm{mg} \cdot \mathrm{dwt} \cdot \mathrm{m}^{-3}(\mathrm{SD} \pm 3.3)$, respectively. During the night time the mean total zooplankton abundance was $3121 \mathrm{ind} \cdot \mathrm{m}^{-3}$ $(\mathrm{SD} \pm 1203)$ and the biomass $21.8 \mathrm{mg} \cdot \mathrm{dwt}^{-\mathrm{m}^{-3}}(\mathrm{SD} \pm 196)$. The total zooplankton abundance during the dry season was numerically dominated by the copepod nauplii and the calanoid copepod, Pseudodiaptomus hessei, which contributed up to $76 \%$ of the total zooplankton counts. The freshwater pulse was associated with the establishment of a horizontal gradient in salinity along the length of the estuary and a significant increase in the total chl- $a$ concentration (range from 0.74 to $11.75 \mu \mathrm{g} \cdot \mathrm{l}^{-1}$ ) and zooplankton biomass (range from 23.7 to $\left.76.6 \mathrm{mg} \cdot \mathrm{dwt} \cdot \mathrm{m}^{-3}\right)(\mathrm{p}<0.05$ in both cases). Additionally, there was a marked increase in the total zooplankton abundances and biomass within the estuary. A distinct shift in the zooplankton community composition was evident with the copepod, Acartia longipatella numerically dominating the zooplankton counts.
\end{abstract}

Keywords: Estuary Zooplankton Community; Freshwater Inflow

\section{Introduction}

Increased population growth coupled with industrialization has coincided with a decrease in the magnitude of freshwater flowing into southern African estuaries. The influence of the reduced freshwater inflow on the biology of southern African estuaries is now well documented [1, 2]. Reduced freshwater inflow into estuaries has been linked to a decrease in the phytoplankton size composition and daily production rates largely because freshwater inflow represents the primary source of nutrients necessary to sustain the growth of the phytoplankton, particularly diatoms $[1,3,4]$. Among the heterotrophic components of the estuarine food web, the alteration in the riverine inflow into estuaries has been linked to changes in the recruitment, biomass and species composition and distribution of both inverstebrates and vertebrates within these systems $[2,5,6]$. The formation of horizontal salin-

"Corresponding author. ity gradients in estuaries is also associated with spatial patterns in the plankton biomass (so-called river-estuary interface (REI) zone [7] Finally, freshwater inflow into estuaries has been linked an increased diversity of niches and food sources available to animals in these systems [8-10].

The Kariega Estuary on the south-east coast of South Africa is regarded as a fresh water deprived system and has been reported as having hypersaline conditions in the upper reaches in various studies since 1991 [11-13]. The hypersaline conditions in the upper reaches of the estuary can be attributed to reduced freshwater inflow as a result of small catchment area $\left(\approx 680 \mathrm{~km}^{2}\right)$, the presence of several impoundments along the Kariega River and high evaporative losses, particularly during the summer months $[12,13]$. Localised flooding occurred during September 2006 along the south-east coast of South Africa, resulting in a horizontal salinity gradient being recorded within the system for the first time since 1991. The biological res- 
ponse to the resumption in freshwater inflow into the estuary has been presented previously $[14,15]$. Results of these studies indicate that the freshwater pulse was associated with the re-establishment of a viable population of the endangered River pipefish, Sygnathus watermeryi, [16], elevated biomass of plankton and fish larvae [15] and increased recruitment of two important sport fishery species in the Kariega Estuary [14]. This manuscript pre- sents the main findings of an investigation that examined the response of the zooplankton community to the freshwater pulse in the freshwater deprived Kariega Estuary.

\section{Study Area}

The Kariega Estuary (Figures 1(a) and (b)) is a permanently open marine dominated system on the southeast

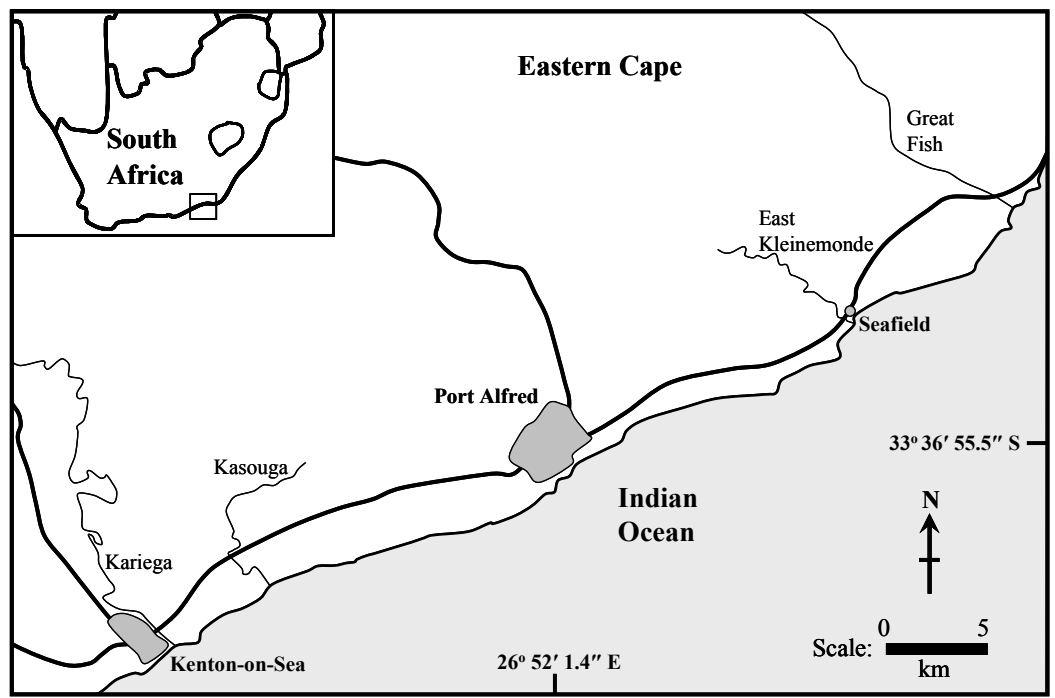

(a)

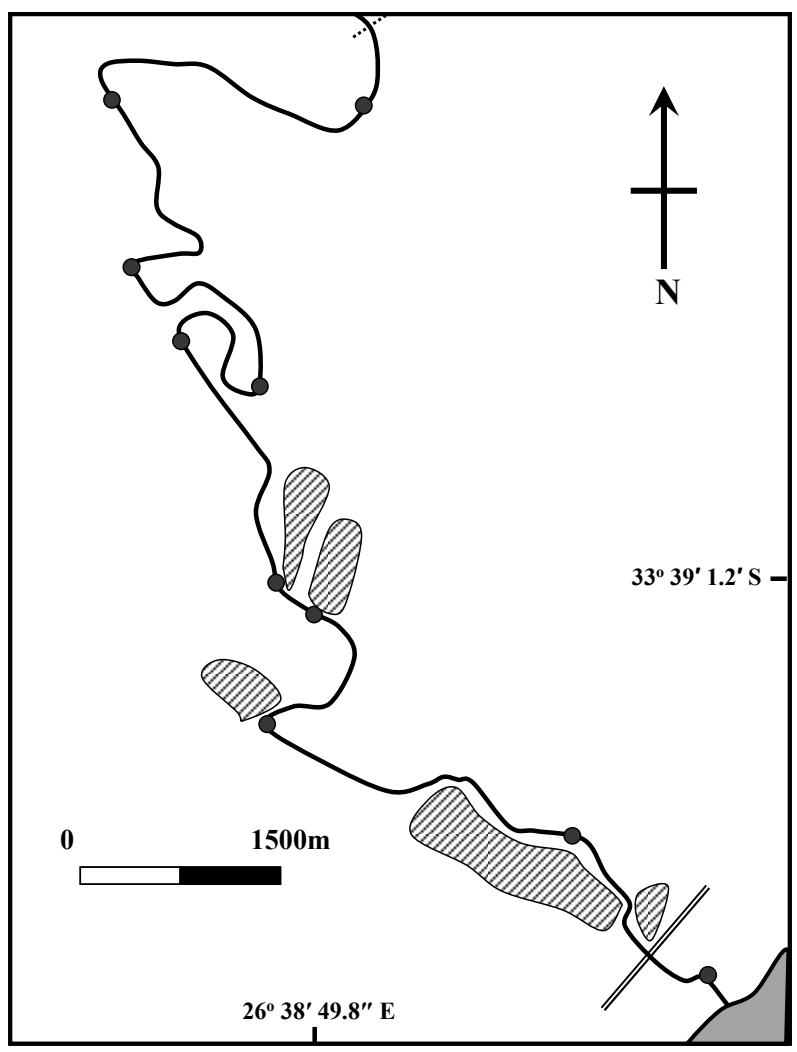

(b)

Figure 1. The study area showing the location of the study estuary along the Eastern cape coast (adapted from Walton 1984). 
coast of South Africa (3340'46.6"S; 26 40'57.9"E) [14] The estuary is approximately $18 \mathrm{~km}$ long, has a depth range of $2.5 \mathrm{~m}$ to $3.5 \mathrm{~m}$ and varies in width between 40 $\mathrm{m}$ and $100 \mathrm{~m}[7,13]$ The estuary is predominantly marine with hypersaline conditions being recorded in the upper reaches since 1991 [3,11,13]. The dominance of the marine environment within the system is indicated by the 106:1 ratio of tidal prism volume to river flow volume [17]. The middle reaches of the estuary are characterised by extensive salt marshes comprising the high marsh plants Sarcocornia perennis, Chenolea diffusa and Spartina maritima. The marine dominance of the system has also contributed to the eelgrass, Zostera capensis, extending its distribution along the length of the estuary $[7,13]$.

\section{Materials and Methods}

Sampling of the zooplankton and related physico-chemical variables was conducted during November 2005 and November 2006. The November 2005 sampling represents the flow rates at present (low flow rates, designnated dry season) within the system, while the November 2006 sampling represents a wet season for the Kariega Estuary. Sampling was conducted at 10 stations along the length of the Kariega Estuary during daylight and night time during low tide.

\subsection{Physico-Chemical Variables}

Temperature and salinity (practical salinity units) at each station were measured using a Horiba U10 water sampler at both the surface and bottom of the water column within the estuary.

\subsection{Chlorophyll-a (chl-a)}

Chlorophyll- $a$ concentrations were determined for surface and bottom waters for each station by collecting 200 $\mathrm{ml}$ water sample using an $8 \mathrm{~L}$ Niskin bottle. These samples were vacuum filtered $(<5 \mathrm{~cm} \mathrm{Hg})$ through $\mathrm{GF} / \mathrm{F}$ filters which were subsequently extracted in $90 \%$ acetone for $24 \mathrm{hr}$ in the dark at $-20^{\circ} \mathrm{C}$. The total chlorophyll- $a$ concentrations were then determined using a 10AU-Turner flourometer before and after acidification according to the method of Holm-Hansen and Riemann [18].

\subsection{Zooplankton}

Zooplankton at each station was collected during three replicate surface tows (depth $\approx 0.5 \mathrm{~m}$ ) conducted during the day and night using a WP-2 Net $(50 \mathrm{~cm}$ diameter, $100 \mu \mathrm{m}$ mesh) fitted with a General Oceanics flow meter to allow for volumetric standardisation of the samples. All samples collected were stored in $10 \%$ buffered formalin for later identification in the laboratory. For each replicate sample the zooplankton dry biomass was determined by filtering a $1 / 2$ to $1 / 32$ sub-sample, obtained using a Folsom plankton splitter, through a pre-weighed $\mathrm{GF} / \mathrm{F}$ filter and then oven drying at $60^{\circ} \mathrm{C}$ for a period of $24 \mathrm{hr}$. The dry biomass was calculated as the difference between the filter weight and the combined dry weight. All zooplankton were counted to allow for density estimates which were then averaged across the three replicate samples. Abundance and biomass values were expressed as ind $\cdot \mathrm{m}^{-3}$ and $\mathrm{mg} \cdot \mathrm{dwt} \cdot \mathrm{m}^{-3}$, respectively.

\subsection{Numerical Analyses}

The average community abundance data for each station was entered into the PRIMER (Plymouth Routines in Multivariate Ecological Research version 5.2.4 software package for comparison between the stations [19]. The data was transformed $(\log (\mathrm{x}+1))$ to minimise the effect of less abundant species and input into a group-averaged Bray-Curtis Similarity analysis from which a cluster diagram was generated. The SIMPER routine was then employed to identify which species were contributing to the differences between the groupings identified with the numerical analysis [19].

\subsection{Statistical Analyses}

To test for differences between wet and dry seasons for chlorophyll concentrations, zooplankton biomass and zooplankton densities, a Lilliefors test for normality was used prior to inputting the data into an ANOVA. These statistical tests were run in the STATISTICA for Windows package [20].

\section{Results}

\subsection{Flow Data}

The monthly flow volumes in the four months preceding the dry season sampling (from June to September) in 2005 , never exceeded $0.026 \times 10^{6} \mathrm{~m}^{3}$ with a maximum occurring in June 2005 (Figure 2). The monthly flow volumes increased from $0.012 \times 10^{6} \mathrm{~m}^{3}$ in June 2006 to $4.45 \times 10^{6} \mathrm{~m}^{3}$ and $2.9 \times 10^{6} \mathrm{~m}^{3}$ in August and September, respectively (Figure 2) (Department of Water Affairs and Forestry Flow Data).

\subsection{Physico-Chemical Variables}

The temperature profiles recorded during both the wet and dry seasons were similar, with a temperature gradient evident from the mouth to the head of the system (Figure 3). Temperatures during the dry season (November 2005) ranged from $19.3^{\circ} \mathrm{C}$ near the mouth to $23.4^{\circ} \mathrm{C}$ at the head of the estuary, while during the wet season (November 2006) the lower reach temperatures were $17.4^{\circ} \mathrm{C}$ with a maximum of $24^{\circ} \mathrm{C}$ at the head. The recorded salinity 


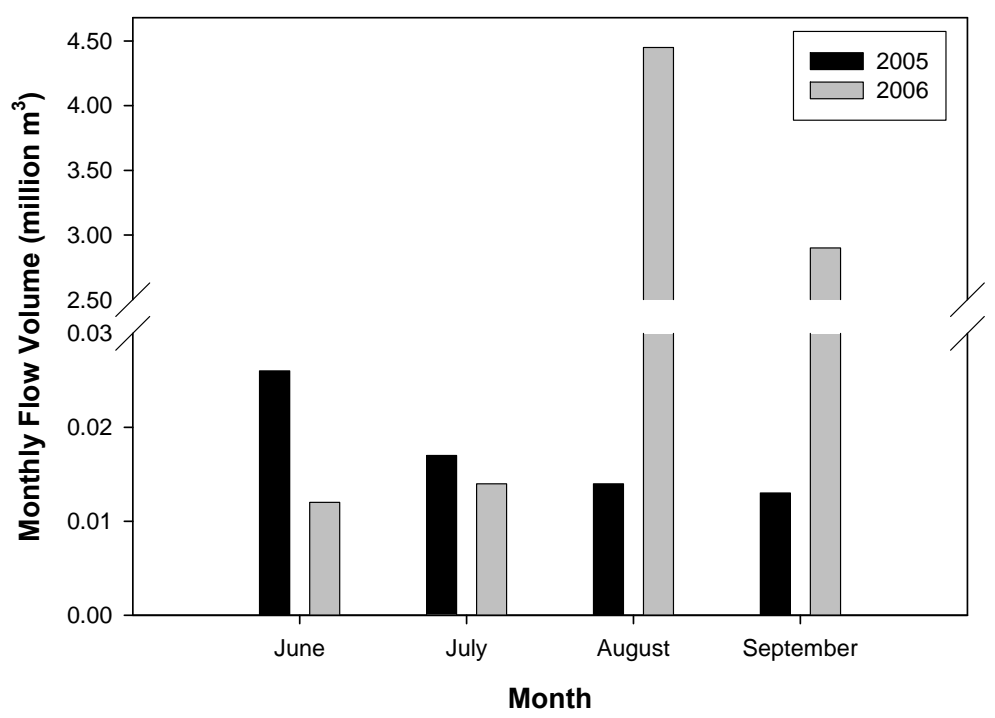

Figure 2. The monthly flow volume (million $\mathrm{m}^{3}$ ) in the months preceding the sampling during 2005 and 2006 (drawn from Department of Water Affairs and Forestry Flow Data).
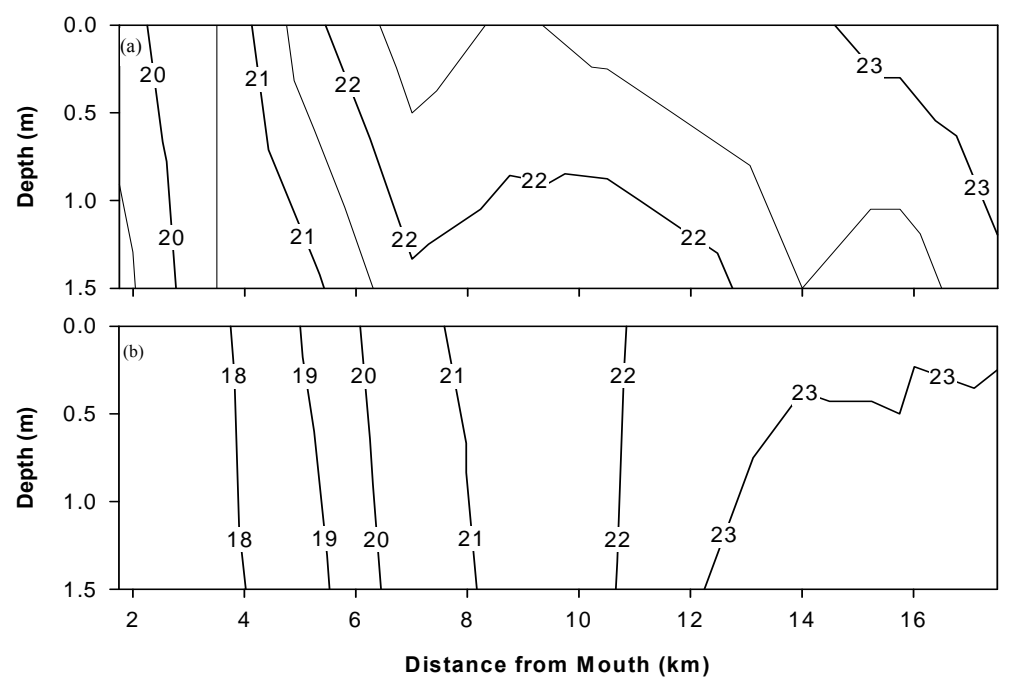

Figure 3. Contour plots of the temperature $\left({ }^{\circ} \mathrm{C}\right)$ in the Kariega Estuary during the dry season, November 2005 (a); and the wet season, November 2006 (b).

demonstrated a reverse salinity gradient during the dry season, with a minimum salinity of 35 near the mouth of the estuary and a maximum of 36.5 near the head of the system (Figure 4). Conversely, during the wet season, a normal salinity gradient was evident, with salinities of 34 recorded at the mouth and 4.7 at the head of the estuary (Figure 4). A salt wedge was also evident in the upper reaches of the system during the wet season, with salinities on the bottom less than 12 .

\subsection{Chlorophyll-a}

The total chlorophyll- $a$ concentration during the dry season was relatively uniform along the length of the estuary, and ranged from $0.25 \mu \mathrm{g} \cdot \mathrm{L}^{-1}$ to $0.61 \mu \mathrm{g} \cdot \mathrm{L}^{-1}$ (Figure 5).
No apparent horizontal or vertical patterns were evident in the total chlorophyll- $a$ concentration during the dry season. During the wet season, the total chlorophyll- $a$ concentration was significantly higher $(\mathrm{p}<0.001 ; \mathrm{F}=$ 34.08), ranging from $0.74 \mu \mathrm{g} \cdot \mathrm{L}^{-1}$ to a maximum of 11.75 $\mu \mathrm{g} \cdot \mathrm{L}^{-1}$. During the wet season the maximum chlorophyll$a$ concentration occurred in the mixing zone between oligohaline and polyhaline conditions approximately $14 \mathrm{~km}$ from the mouth (Figures 4 and 5).

\subsection{Zooplankton}

Daytime dry season densities of zooplankton ranged from 432 ind $\cdot \mathrm{m}^{-3}$ to $936 \mathrm{ind} \cdot \mathrm{m}^{-3}$, while during the wet season total zooplankton densities varied between 76 

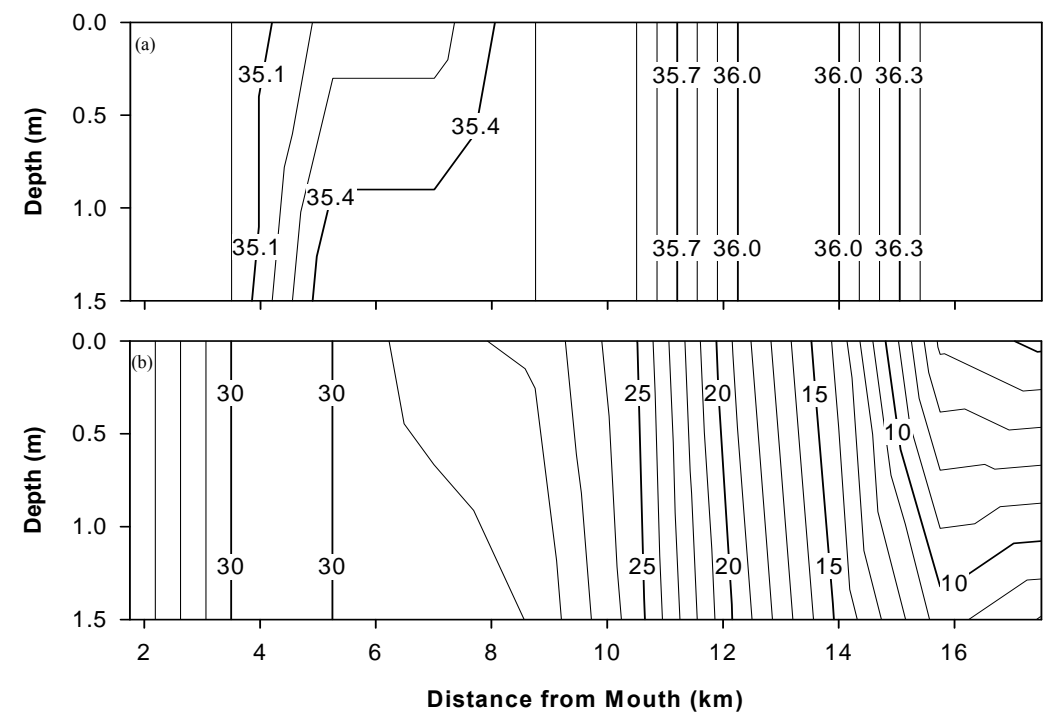

Figure 4. Contour plots of the salinity (practical salinity units) in the Kariega Estuary during the dry season, November 2005 (a); and the wet season, November 2006 (b).
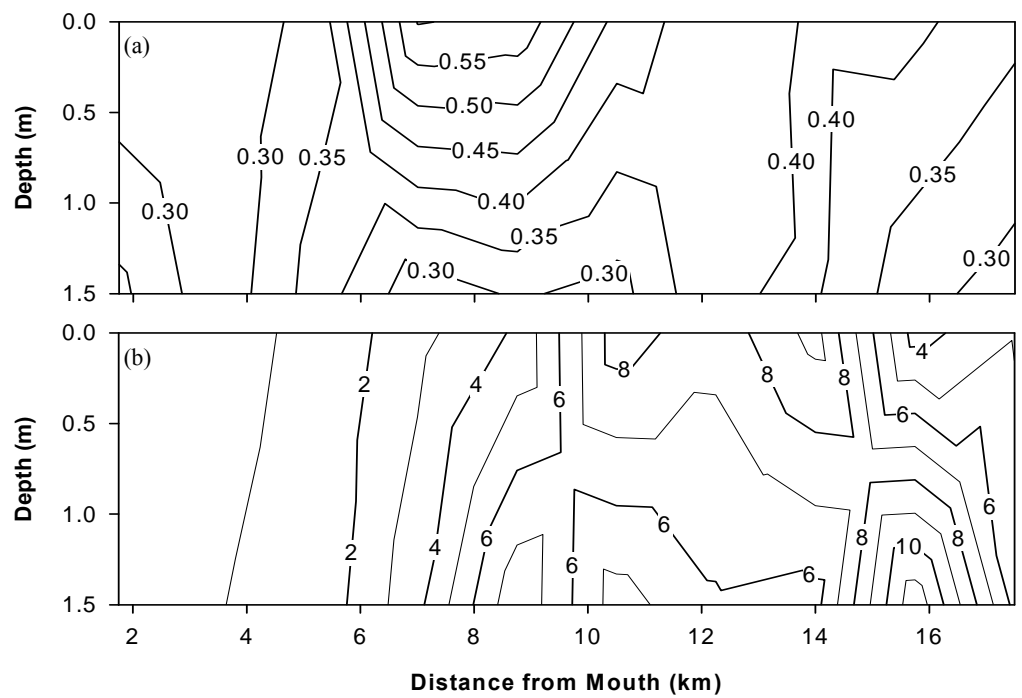

Figure 5. Contour plots of the total chlorophyll-a concentration $\left(\mu \mathrm{g} \cdot \mathrm{L}^{-1}\right)$ in the Kariega Estuary during the dry season, November 2005 (a); and the wet season, November 2006 (b).

ind $\cdot \mathrm{m}^{-3}$ and $11180 \mathrm{ind} \cdot \mathrm{m}^{-3}$ (Figures 6(a) and (b)). The night time densities during the dry season were significantly lower than those recorded for the wet season $(\mathrm{p}<$ $0.03 ; \mathrm{F}=6.39$ ), with mean densities of 3121 ind $\cdot \mathrm{m}^{-3}$ $( \pm 1203 \mathrm{SD})$ recorded during the dry season and 14,270 ind $\cdot \mathrm{m}^{-3}( \pm 13900.53 \mathrm{SD})$ recorded during the wet season (Table 1). The horizontal trends demonstrated relatively uniform densities throughout the estuary during the dry season and higher densities in the lower and middle reaches during the wet season (Figures 6(a) and 7(b)). The observed peak in densities during both day and night time sampling during the wet season occurred at a polyhaline salinity and at the surface chlorophyll maximum.

Daytime total zooplankton biomass demonstrated no significant differences $(\mathrm{p}<0.05)$ between seasons, ranging between $9.0 \mathrm{mg} \cdot \mathrm{dwt} \cdot \mathrm{m}^{-3}$ and $16.7 \mathrm{mg} \cdot \mathrm{dwt} \cdot \mathrm{m}^{-3}$ during the dry season and from $5.8 \mathrm{mg} \cdot \mathrm{dwt} \cdot \mathrm{m}^{-3}$ to 73.8 $\mathrm{mg} \cdot \mathrm{dwt} \cdot \mathrm{m}^{-3}$ during the wet season (Figures 6(c) and (d)). The night time biomass, however, demonstrated a significant increase from dry to wet season $(\mathrm{p}<0.01 ; \mathrm{F}=$ 11.34). The mean dry season night time biomass was $21.75 \mathrm{mg} \cdot \mathrm{dwt} \cdot \mathrm{m}^{-3}( \pm 3.33 \mathrm{SD})$, while the mean wet season biomass was estimated at $50.16 \mathrm{mg} \cdot \mathrm{dwt} \cdot \mathrm{m}^{-3}( \pm 26.46$ SD) (Table 1). During the dry season the total zooplankton biomass was relatively uniform throughout the estuary during both day and night samples, while during the wet season the biomass was highest in the lower and middle reaches of the system (Figures 6(c) and $\mathbf{7 ( d )}$ ). 

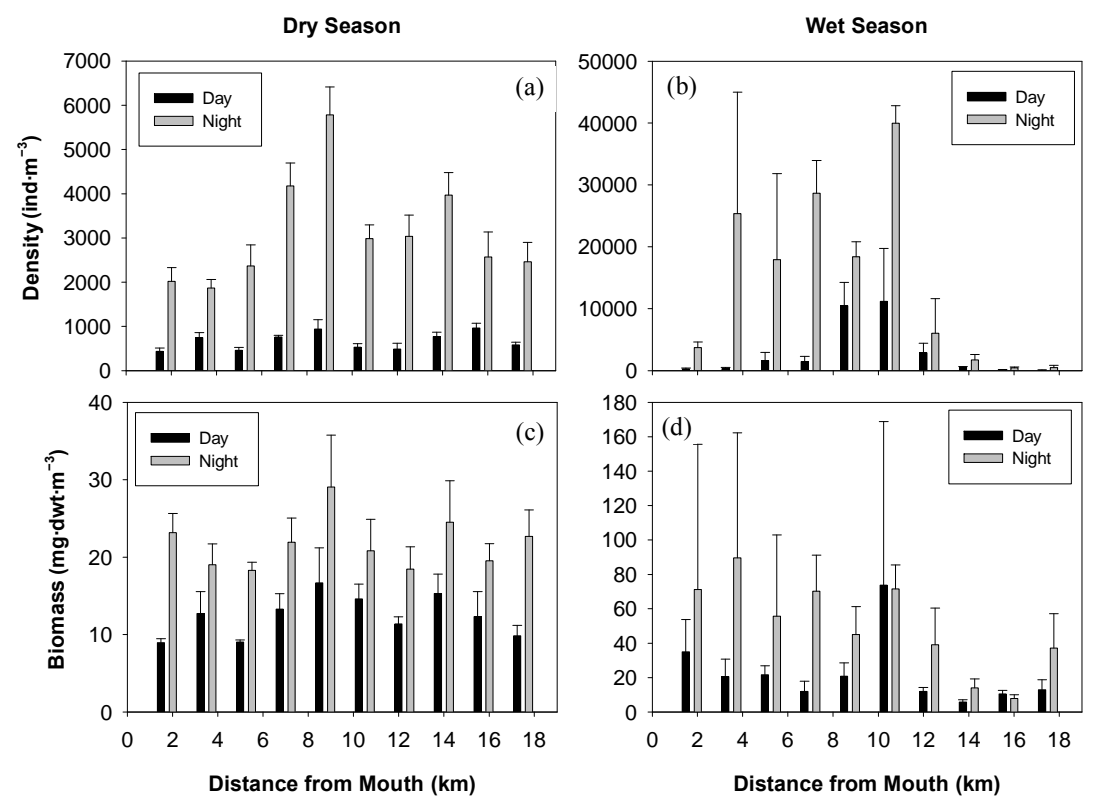

Figure 6. The mean zooplankton biomass and density recorded during day and night surveys. Error bars represent the standard deviation. (a) = dry season zooplankton biomass; (b) = wet season zooplankton biomass; (c) = dry season density; (d) = wet season density. Note the different scales on the $y$-axes.

Table 1. The mean zooplankton biomass $\left(\mathrm{mg} \cdot \mathrm{dwt} \cdot \mathrm{m}^{-3}\right)$ and density (ind $\cdot \mathrm{m}^{-3}$ ) during the day and night for both seasons. Standard deviations, minimum and maximum recorded values are also presented.

\begin{tabular}{cccccc}
\hline & & Dry & & \multicolumn{2}{c}{ Wet } \\
\cline { 3 - 6 } & & Day & Night & Day & Night \\
\hline \multirow{2}{*}{ Biomass } & Mean & 12.42 & 21.75 & 22.49 & 50.16 \\
& SD & 2.65 & 3.33 & 19.80 & 26.46 \\
& Max & 16.67 & 29.06 & 73.79 & 89.64 \\
& Min & 8.96 & 18.29 & 5.79 & 7.86 \\
& Mean & 666.20 & 3121.20 & 2891.52 & 14270.37 \\
& SD & 196.34 & 1203.89 & 4276.58 & 13900.53 \\
& Max & 964.0 & 5780.0 & 11180.15 & 39962.84 \\
& Min & 432.0 & 1864.0 & 76.32 & 436.60 \\
\hline
\end{tabular}

\subsection{Numerical Analyses}

The numerical analyses of the zooplankton density data resulted in a significantly different separation $(p=0.001$; $\mathrm{R}=0.861)$ between the wet and dry seasons at approximately $45 \%$ similarity level (Figure 7). A further separation was evident during the dry season between the lower reach stations (designated Marine Dry Group) and the remainder of the estuary at approximately $75 \%$ similarity. ANOSIM indicated differences between the two groupings were significant $(p<0.05)$. The separation between the lower reach stations and the remaining stations could largely be ascribed to the increased contribution of marine species to the total counts including copepods from the genera Oithona, Eucalanus and Calanus (Table 2).

During the wet season a longitudinal separation oc- curred with the upper reach stations separating from the remaining stations at approximately 50\% similarity (Figure 7). Again, ANOSIM indicated differences between the two groupings were significant $(p<0.05)$. SIMPER analysis indicated that the separation of the upper stations from the remaining station could largely be ascribed to reductions in the abundances of the numerically dominant species rather than the presence of individual species.

\section{Discussion}

Despite the permanently open nature of the Kariega Estuary, the system is currently highly impacted due to fresh water deprivation resulting from impoundments along the Kariega River [4,17]. The recorded normal 


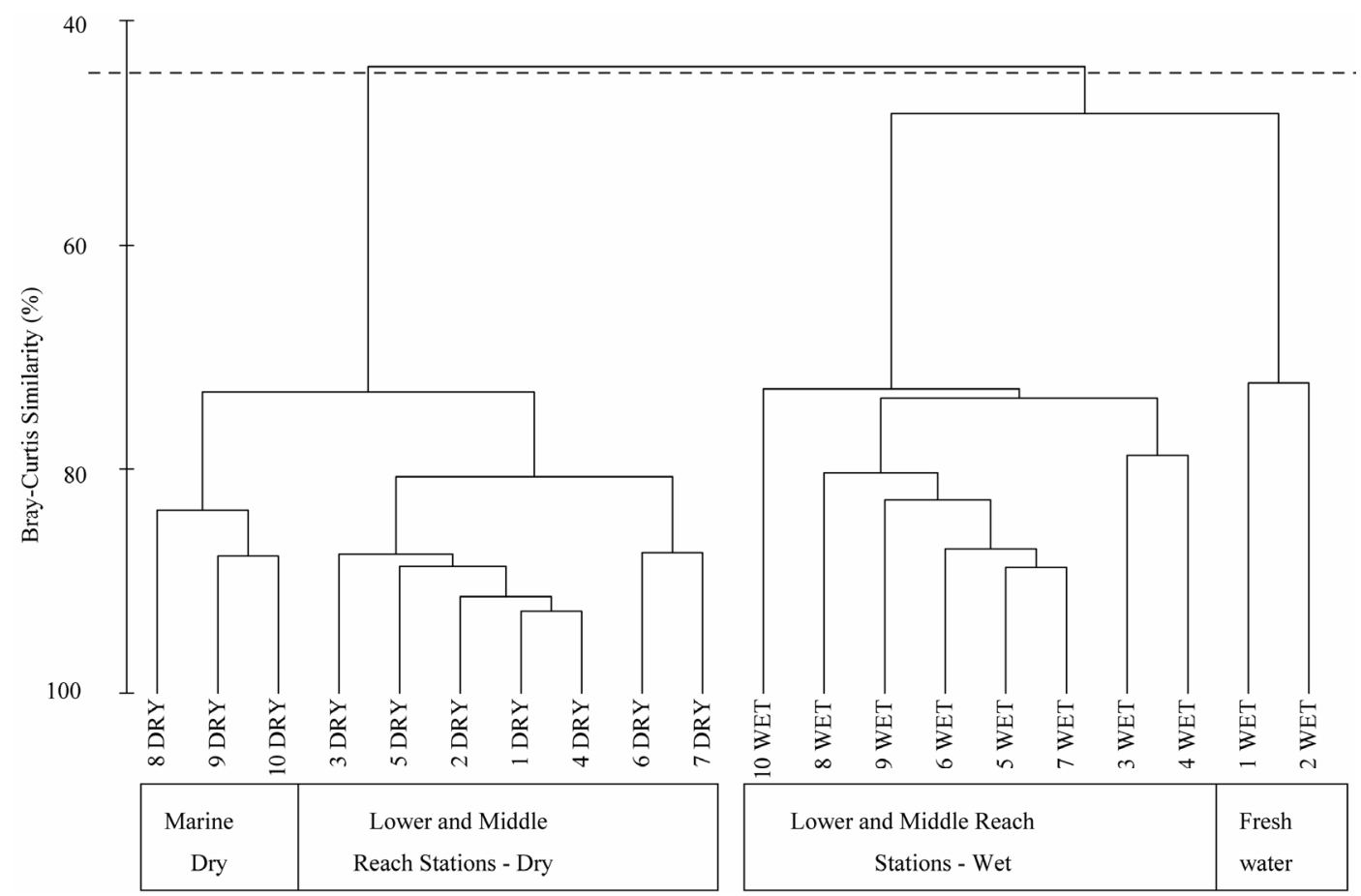

Figure 7. The numerical analyses of the night time zooplankton communities at each site during the wet and dry seasons. The dotted line represents a $45 \%$ similarity.

Table 2. Mean abundances of the five most numerically abundant zooplankton accounting for up to $78 \%$ of the similarity within each grouping identified with the hierarchical cluster analysis.

\begin{tabular}{|c|c|c|c|c|c|c|c|}
\hline \multicolumn{2}{|l|}{ Marine-dry } & \multicolumn{2}{|c|}{ Middle and upper reaches-dry } & \multicolumn{2}{|l|}{ Freshwater-wet } & \multicolumn{2}{|c|}{ Middle and lower reaches-wet } \\
\hline Species & $\begin{array}{l}\text { Average } \\
\text { abundance } \\
\text { (ind } \cdot \mathrm{m}^{-3} \text { ) }\end{array}$ & Species & $\begin{array}{l}\text { Average } \\
\text { abundance } \\
\text { (ind } \cdot \mathrm{m}^{-3} \text { ) }\end{array}$ & Species & $\begin{array}{l}\text { Average } \\
\text { abundance } \\
\text { (ind } \cdot \mathrm{m}^{-3} \text { ) }\end{array}$ & Species & $\begin{array}{l}\text { Average } \\
\text { abundance } \\
\left(\text { ind } \cdot \mathrm{m}^{-3} \text { ) }\right.\end{array}$ \\
\hline Oithona nana & 33.3 & Copepod nauplii & 1897.1 & A.longipatella & 131.5 & A.longipatella & 13379.5 \\
\hline Eucalanus sp. & 14.7 & P.hessei & 909.4 & P.hessei & 62.1 & P.hessei & 2607.8 \\
\hline Calanus simillimus & 31.3 & A.longipatella & 343.1 & Halicyclops sp. & 105.3 & Copepod nauplii & 1313.4 \\
\hline Pseudodiaptomus hessei & 450.0 & Halicyclops sp. & 81.7 & Copepod nauplii & 30.5 & Ostracod & 289.6 \\
\hline Copepod nauplii & 1267.7 & Tortanus capensis & 34.9 & Ostracod & 6.1 & & \\
\hline
\end{tabular}

flow rate of $\approx 0.003 \mathrm{~m}^{3} \cdot \mathrm{s}^{-1}$ (Department of Water Affairs and Forestry Flow Data) regularly results in hypersaline conditions predominating in the upper reaches of the estuary $[11,13,21]$. This study examined the response of the plankton to a fresh water pulse resulting from prolonged heavy rainfall within the catchment area over a two-month period. Both the temperature and salinity profiles demonstrate a well-mixed marine dominated lower to middle reaches of the estuary during both the dry and wet seasons (Figures 4 and 5). The difference in the water column characteristics between the dry and wet season was evident in the upper reaches of the system. During the wet season, a distinct salt wedge was evident in the headwaters of the estuary while hypersaline conditions predominated in the upper reaches during the dry season (Figure 4).
The total chlorophyll-a concentration during the wet season (range 0.74 to $11.5 \mu \mathrm{g} \cdot \mathrm{l}^{-1}$ ) was significantly higher than during the dry season (range 0.25 to 0.60 $\left.\mu \mathrm{g} \cdot \mathrm{l}^{-1}\right)(\mathrm{p}<0.05)$. The increase in the total chl- $a$ concentration in freshwater dominated estuaries is largely thought to be result of elevated phytoplankton production rates resulting from increased macronutrient availability $[1,3,17]$. Alternatively, it is also possible that the elevated total chlorophyll- $a$ concentrations recorded during the wet season may have be derived from riverine input or the resuspension of microphytobenthic algae $[4,13$, $17]$.

The total zooplankton abundances and biomass attained the highest levels during the wet phase (Figure 3). Shifts in the total zooplankton abundances and biomass within southern African estuaries and indeed estuaries 
worldwide, have been reported to be related to the interactive effects of temperature and food availability $[2,5,17]$ The influence of temperature can largely be discounted as water temperatures were broadly similar during the two seasons The significant increase in zooplankton density and biomass recorded from dry to wet season during this study is, therefore, likely to be the result of elevated food availability. While the dry season biomass and densities values are in the range reported for Kariega Estuary, the wet season densities and biomass are substantially higher and are in the range reported for permanently open southern African estuaries with sustained freshwater inflow [2-4,13]. Results of the hierarchical cluster analyses indicated that the wet and dry seasons were characterised by distinct zooplankton communities (Figure 7). The species which demonstrated the greatest increase in numbers between dry and wet season was the copepod, Acartia longipatella, which contributed $\approx 8.5 \%$ of the total abundance during the dry season, but represented $\approx 75 \%$ of the total abundance during the wet season. Although the actual abundances of Pseudodiaptomus hessei increased from dry to wet season, the percentage contribution of the total abundance decreased from $\approx 25 \%$ to $15 \%$. Successional patterns of copepods within southern African estuaries are largely driven by alterations in salinity [2]. Acartia longipatella reportedly attains the highest abundances and biomass during periods when oligohaline conditions prevail $[2,5,21]$. Conversely, the calanoid copepod, $P$. hessei can be considered as a pioneer species able to tolerate a high variance in salinity and temperature $[2,21,22]$. The observed shift in the numerically dominant copepod species from the dry to wet phase can therefore be attributed to a change in the salinity regime within the estuary resulting from the freshwater pulse.

Results of the numerical analyses conducted during the dry and wet season indicated the presence of a longitudinal gradient in the zooplankton assemblages within the Kariega estuary. During the dry season, those stations occupied in the lower reaches of the estuary were distinct from the stations within the middle and upper reaches of the system. The clear separation of the two groupings could largely be attributed to the increased contribution of marine species (copepods of the genera Oithona, Eucalanus and Calanus) to the total counts at stations in the lower reaches reflecting the influence of the marine environment on the estuary. On the other hand, during the wet season, the upper reach stations separated from those occupied within the middle and lower reaches of the estuary. SIMPER analyses indicated that the separation could be largely ascribed to reductions in the numerical abundances of the dominant copepods within the upper reaches of the estuary. The reduced abundances within the upper reaches can probably be ascribed to the inflow of freshwater which would prevent the build up of zooplankton biomass within the region.

Results of this study indicate that the freshwater pulse into the Kariega Estuary was associated with an increase in the zooplankton biomass and a shift in the zooplankton species composition. The horizontal patterns in zooplankton community structure and biomass can be ascribed hydrodynamics of the estuary, reflecting both the magnitude of freshwater inflow into the system and the influence of the marine environment on the lower reaches of the estuary. The increase in the phytoplankton biomass associated with the freshwater inflow is also likely to be associated with a change in the food web structure from a detrital food web to one where the classical food web predominates [23]. Additionally, the outflow of estuarine water is also likely to be associated with elevated primary and secondary production rates in the near shore marine environment [24].

\section{Acknowledgements}

The authors would like to thank the National Research Foundation (NRF) of South Africa and the South African Observation Network (SAEON) Elwandle Node for providing funds and facilities tocomplete this study.

\section{REFERENCES}

[1] J. Adams, G. Bate and M. O'Callagan, "Estuarine Microalgae," In: B. R. Allanson and D. Baird, Eds., Estuaries of South Africa, Cambridge University Press, Cambridge, 1999, pp. 91-100.

[2] T. H. Wooldridge, "Estuarine Zooplankton Community Structure and Dynamics," In: B. R. Allanson and D. Baird, Eds., Estuaries of South Africa, Cambridge University Press, Cambridge, 1999, pp. 91-100.

[3] B. R. Allanson and G. H. L. Read, "Further Comment on the Response of Eastern Cape Province Estuaries to Variable Freshwater Inflows," South African Journal of Aquatic Science, Vol. 21, 1995, pp. 56-70.

[4] N. Grange and B. R. Allanson, "The Influence of Freshwater Inflow on the Nature, Amount and Distribution of Seston in Estuaries of the Eastern Cape, South Africa," Estuarine, Coastal and Shelf Science, Vol. 40, No. 4, 1995, pp. 403-420. doi:10.1006/ecss.1995.0028

[5] H. L. Jerling and T. H. Wooldridge, "Plankton Distribution and Abundance in the Sundays River Estuary, South Africa, with Comments on Potential Feeding Interactions," South African Journal of Marine Science, Vol. 15, 1995, pp. 169-184. doi:10.2989/02577619509504842

[6] P. D. Vorwerk, “A Preliminary Examination of Selected Biological Links between four Eastern Cape Estuaries and the Inshore Marine Environment," Ph.D. Thesis, Rhodes University, Grahamstown, 2006, pp. 1-268.

[7] G. C. Bate, A. K. Whitfield, J. B. Adams, P. Huizinger and T. H. Wooldridge, "The Importance of the River-Estuary Interface (REI) Zone in Estuaries," Water SA, Vol. 
28, No. 3, 2002, pp. 271-279.

[8] A. K. Whitfield and M. N. Bruton, "Some Biological Implications of Reduced Fresh Water Inflow into Eastern Cape Estuaries: A Preliminary Assessment," South African Journal of Science, Vol. 85, 1989, pp. 691-694.

[9] L. D. Ter, E. R. Morshuizen and A. K. Whitfield, "The Distribution of Littoral Fish Associated with Eelgrass Zostera capensis in the Kariega Estuary, a Southern African System with a Reversed Salinity Gradient," South African Journal of Marine Science, Vol. 14, 1994, pp. 95105. doi:10.2989/025776194784287049

[10] A. K. Whitfield and T. H. Wooldridge, "Changes in Freshwater Supplies to Southern African Estuaries: Some Theoretical and Practical Considerations," In: K. R. Dyer and R. J. Orth, Eds., Changes in Fluxes in Estuaries: Implications from Science to Management, Olsen \& Olsen, Fredensborg, 1994, pp. 41-50.

[11] L. D. Ter Morshuizen, A. K. Whitfield and A. W. Paterson, "Influence of Freshwater Flow Regime on Fish Assemblages in the Great Fish River and Estuary," South African Journal of Aquatic Science, Vol. 22, 1996, pp. 52-61.

[12] A. K. Whitfield and A. W. Paterson, "Distribution Patterns of Fishes in a Freshwater Deprived Eastern Cape Estuary, with Particular Emphasis on the Geographical Headwater Region," Water SA, Vol. 29, No. 1, 2003, pp. 61-67.

[13] E. E. Heyns and P. W. Froneman, "Spatial and Temporal Patterns in the Hyperbenthic Community Structure in Southern African Permanently Open Estuary," Estuarine, Coastal and Shelf Science, Vol. 88, 2010, pp. 105-115.

[14] P. D. Vorwerk, A. W. Paterson, P. W. Froneman and A. K. Whitfield, "Increased Abundance of Two Important Sport Fishery Species Following Renewed River Flow into a Freshwater Deprived South African Estuary," Fisheries Management and Ecology, Vol. 16, No. 5, 2009, pp. 420-423. doi:10.1111/j.1365-2400.2009.00687.x

[15] P. D. Vorwerk, P. W. Froneman, A. W. Paterson, N. A. Strydom and A. K. Whitfield, "Biological Responses to a Resumption in River Flow in a Freshwater Deprived, Permanently Open Southern African Estuary," Water SA, Vol. 34, No. 5, 2008, pp. 597-604.
[16] P. D. Vorwerk, P. W. Froneman and A. W. Paterson, "Revival of the Critically Endangered River Pipefish, Syngnathus watermeyeri, in Eastern Cape Estuaries," South African Journal of Science, Vol. 103, 2007, pp. 193-195.

[17] N. Grange, A. K. Whitfield, C. J. De Villiers and B. R. Allanson, "The Response of Two South African East Coast Estuaries to Altered River Flow Regimes," Aquatic Conservation: Marine and Freshwater Ecosystems, Vol. 10, No. 3, 2000, pp. 155-177. doi:10.1002/1099-0755(200005/06)10:3<155::AID-AQC 406>3.0.CO;2-Z

[18] O. Holm-Hansen and B. Riemann, "Chlorophyll-a Determination: Improvements in Methodology," Oikos, Vol. 30, No. 3, 1978, pp. 438-447. doi:10.2307/3543338

[19] K. R. Clarke and R. M. Warwick, "Change in Marine Communities: An Approach to Statistical Analysis and Interpretation," Plymouth Marine Laboratory, Plymouth, 1994.

[20] Statsoft Inc., "Statistica, Data Analysis Software System," Version 7, 2004

[21] N. A. Strydom, A. K. Whitfield, A. W. Paterson, N. A. Strydom, A. K. Whitfield and A. W. Paterson, "Influence of Altered Freshwater Flow Regimes on Abundance of Larval and Juvenile Gilchristella aestuaria (Pisces: Clupeidae) in the Upper Reaches of Two South African Estuaries," Marine and Freshwater Research, Vol. 69, 2002, pp. 178-189.

[22] P. W. Froneman, "Response of the Plankton to Three Different Hydrological Phases of the Temporarily Open/ Closed Kasouga Estuary, South Africa," Estuarine, Coastal and Shelf Science, Vol. 55, 2002, pp. 535-546. doi:10.1006/ecss.2001.0921

[23] A. W. Paterson and A. K. Whitfield, "A Stable Carbon Isotope Study of the Food-Web in a Freshwater-Deprived South African Estuary, with Particular Emphasis on the Ichthyofauna," Estuarine, Coastal and Shelf Science, Vol. 45, 1997, pp. 705-715. doi:10.1006/ecss.1997.0243

[24] P. D. Vorwerk and P. W. Froneman, "The Importance of Estuarine Derived Carbon for the Near Shore Marine Environment: Studies on Contrasting Southern African Estuaries," African Journal of Aquatic Science, Vol. 34, 2009 , pp. 67-77. doi:10.2989/AJAS.2009.34.2.4.891 